$\S=-1$

\title{
Strength Characteristics of GGBS and Steel Slag based Binary Mix Concrete
}

\author{
K. K.Siddhartha ${ }^{1}$, P.Bhuvaneshwari ${ }^{2 *}$, Saravana Raja Mohan.K ${ }^{3}$ \\ School of Civil Engineering, SASTRA Deemed University, Thanjavur, India \\ *Corresponding Author E-mail: ${ }^{3}$ bhuvaneswari@ civil.sastra.edu
}

\begin{abstract}
The objective of this study is to experimentally study the effect of partial replacement of Portland cement and fine aggregate by the industrial wastes ground granulated blast furnace slag (GGBS) and steel slag (SS) respectively, on the various strength parameters of concrete. Totally 9 mixes were proposed according to ACI standards, with varying replacements of cement with $40 \%, 50 \%$ and $60 \%$ of GGBS and varying replacement of fine aggregate with steel slag by 10\%, 20\% and $30 \%$ weight of concrete. The compressive strength using cubes of size $100 \mathrm{~mm}$ x $100 \mathrm{~mm}$ x $100 \mathrm{~mm}$ and splitting tensile strength using cylinder of size $100 \mathrm{~mm} \times 200 \mathrm{~mm}$ were found out for curing periods of 14 and 28 days respectively for all the mixes. Results were then compared with conventional concrete and the optimum replacement percentage of GGBS and steel slag is reported.
\end{abstract}

Keywords: Ground granulated blast furnace slag; Steel slag; Compressive strength; Tensile strength.

\section{Introduction}

Research on alternate binders and supplementary cementitious materials has been going on for many years. The cement productionis a highly energy intensive process which consumes a high amount of energy. For the manufacture of Portland cement, each ton of its produce releases 1 ton of carbon dioxide approximately[1]. The production of cement contributes to around $5 \%$ of the global greenhouse gas emissions [2]. Use of industrial by-products as replacement to the cement will reduce the quantity of cement used in construction. This will result in reducing the energy for the cement manufacture thereby reducing the greenhouse gases emissions. The use of the industrial byproductGGBS in concrete, which would contribute to land pollution, will reduce the greenhouse gas emissions from construction industry.

The use of ground granulated blast furnace slag (GGBS) and steel furnace slag (SFS) in construction has been in practice from a long time, going as far back asa century in the United States and about 150 years in Europe [3]. The possible use of steel slag with benefits related to technological and ecological aspects were studied from researches [4, 5].

Partial replacement of cement with high percentages of ground granulated blast furnace slag was tested for compressive strength and flexural strength. The optimum amount of replacement was found out to be 55\% [6]. The optimum replacement percentage forsteel slag in place of fine aggregate was found to be $40 \%$ [7] while using unprocessed steel slag increased strength up to $30 \%$ of replacement [8].

\subsection{Research Significance}

The main objective of this research is to find the optimum percentage of combined partial replacement of cement with the industrial waste ground granulated blast furnace slag (GGBS) and the partial replacement of fine aggregate with SS with respect to the compressive strength and the splitting strength of the slag based concrete. This will help reduce the usage of cement without forsaking the strength of the concrete. Also the requirement of huge amounts of sand can be tackled with the help of steel slag replacing sand.

\section{Materials and Methods}

\subsection{Materials Used}

The materials used to study the characteristic strength of concrete constitute of cement, GGBS, steel slag, M-sand, $12.5 \mathrm{~mm}$ aggregates. Cement utilized for the study was ordinary Portland cement of 43 grade confirming [9]. Ground granulated blast furnace slag having a specific gravity of 2.6 was used to partially replace cement in various percentages as shown in table 1. M-sand passing through a sieve of $4.75 \mathrm{~mm}$ having a specific gravity of 2.81 was used as fine aggregate. Steel slag of specific gravity 2.8 which was having a fineness modulus of 2.78 was used for partial replacement of fine aggregate and the following mix proportions were proposed (Table 1).

\subsection{Methods}

Mix proportion according to ACI standards is proposed for a target strength of M60 [10]. High binder content of $504.21 \mathrm{~kg} / \mathrm{m} 3$ is casted with M-sand as fine aggregate of $683.24 \mathrm{~kg} / \mathrm{m} 3$ and coarse aggregate of size $12.5 \mathrm{~mm}$ of $1108.1 \mathrm{~kg} / \mathrm{m} 3$. The fine aggregate used with particle size confirmed tothe requirements of ASTM C33 [11]. The following mix proportion table gives the content of cement, GGBS, M-sand, steel slag and coarse aggregate. Cement was then replaced with varying percentages of GGBS as $40 \%, 50 \%$, and $60 \%$ by weight of cement whereas Msand was replaced with steel slag in different percentages of $10 \%$, $20 \%$, and $30 \%$. For example, the mix G4S1 is a mix with cement 
replaced with $40 \%$ of GGBS by weight of cement, fine aggregate M-sand replaced with $10 \%$ of steel slag by weight of fine aggregate. In this respective, a total of 9 mixes were proposed. A water-cement ratio of 0.29 is taken and the water content is 141.6 $\mathrm{kg} / \mathrm{m} 3$. Polycarboxylate is used as super plasticizer and is added as $1.7 \%$ to the weight of cement content.

Table 1: Mix Proportion $\left(\mathrm{kg} / \mathrm{m}^{3}\right)$

\begin{tabular}{|c|c|c|c|c|c|}
\hline Specimen & Cement & GGBS & M-sand & $\begin{array}{c}\text { Steel } \\
\text { Slag }\end{array}$ & $\begin{array}{c}\text { Coarse } \\
\text { Aggregate }\end{array}$ \\
\hline Control & 504.21 & 0 & 683.2 & 0 & 1108.1 \\
\hline G4S1 & 302.5 & 201.7 & 614.9 & 68.3 & 1108.1 \\
\hline G5S1 & 252.1 & 252.1 & 614.9 & 68.3 & 1108.1 \\
\hline G6S1 & 201.7 & 302.5 & 614.9 & 68.3 & 1108.1 \\
\hline G4S2 & 302.5 & 201.7 & 546.6 & 136.6 & 1108.1 \\
\hline G5S2 & 252.1 & 252.1 & 546.6 & 136.6 & 1108.1 \\
\hline G6S2 & 201.7 & 302.5 & 546.6 & 136.6 & 1108.1 \\
\hline G4S3 & 302.5 & 201.7 & 478.3 & 205 & 1108.1 \\
\hline G5S3 & 252.1 & 252.1 & 478.3 & 205 & 1108.1 \\
\hline G6S3 & 201.7 & 302.5 & 478.3 & 205 & 1108.1 \\
\hline
\end{tabular}

\subsection{Compressive Strength}

The compressive strength of the binary mix was measured with the help of cube compressive strength of $100 \mathrm{~mm}$ x $100 \mathrm{~mm}$ x 100 $\mathrm{mm}$ cubes confirming to the code [12]. The cube specimens were casted in the order of the proportions as shown in table 1 . Required amount of GGBS was taken and mixed with cement to form the binder for the concrete. These were further mixed with steel slag and M-sand. Coarse aggregates of $12.5 \mathrm{~mm}$ were added to the mixture and sufficient water, including super plasticizer is poured into the mix to get the concrete. This is then molded into cubes of dimensions, $100 \mathrm{~mm} \times 100 \mathrm{~mm} \times 100 \mathrm{~mm}$. After 24 hrs.the cubes were de molded and kept under curing for curing periods of 14 days and for 28 days. After 14 days and 28 days, the cubes were taken out of curing phase and kept in the open air for about 1 day and tested for strength.

\subsection{Splitting Tensile Strength}

The splitting tensile strength of concrete was measured using 100 mm length $x 200 \mathrm{~mm}$ diameter cylinders [13]. The cylinders were casted in plastic PVC pipes which were molded to the requirement. The cylinders were carefully de molded and kept for the same number of curing period as of cubes, i.e., 14 days and 28 days. 9 mixes were casted and after curing for 14 and 28 days, they were tested under ACTM.

\section{Results and Discussions}

In this section, the results obtained from the ACTM are reported in tables (tables 2,3) and are comprehensively compared with each other as well as with control concrete. The trend of increase or decrease in strength is discussed as follows.

\subsection{Compressive Strength}

The compressive strength was conducted in the automatic compression testing machine (ACTM) at a loading rate of 2.9 $\mathrm{kN} / \mathrm{s}$. (refer fig. 1). The results are published in table 2. A comparative analysis reported as follows.

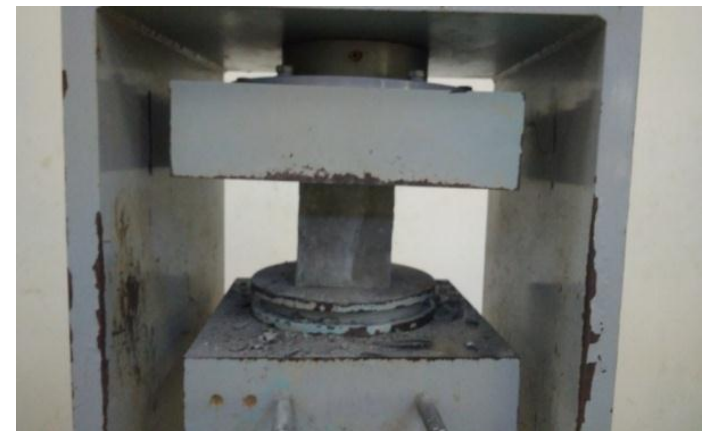

Fig. 1: Compressive strength test setup

Table 2: Compressive strength (MPa)

\begin{tabular}{|l|l|l|}
\hline Specimen & 14 days strength & 28 days strength \\
\hline Control & 31.01 & 50.65 \\
\hline G4S1 & 20.91 & 28.63 \\
\hline G5S1 & 35.03 & 40.3 \\
\hline G6S1 & 37.46 & 39.2 \\
\hline G4S2 & 21.01 & 25.34 \\
\hline G5S2 & 36.74 & 40.87 \\
\hline G6S2 & 40.49 & 48.87 \\
\hline G4S3 & 23.58 & 37.26 \\
\hline G5S3 & 37.98 & 47.34 \\
\hline G6S3 & 44.11 & 54.78 \\
\hline
\end{tabular}

The compressive strength reduces when compared to control concrete but the strength increases as the GGBS amount in the concrete increases. The percentage increase itself decreases with the increase in the quantity of GGBS. For example the compressive strength of G4S1 is $20.91 \mathrm{MPa}$ for 14 days while that of control concrete is $31.01 \mathrm{MPa}$. There is a clear reduction in strength. As the GGBS quantity is increased form $40 \%$ by weight of concrete to $50 \%$ by weight of concrete, the strength increases to $35.03 \mathrm{MPa}$. The percentage increase is $67.53 \%$, whereas the percentage increase from $50 \%$ replacement to $60 \%$ replacement of GGBS is $6.93 \%$ only. From this we can infer that the effect of GGBS in the strength decreases as its quantity increased further $60 \%$ replacement by weight.

Contrary to the GGBS addition, the addition of steel slag increased the compressive strength as can be seen from the percentage increase with $10 \%$ fine aggregate replacement and $20 \%$ fine aggregate replacement.

Together, addition of GGBS and steel slag gives good strength. The percentage increase in strength for G6S3 compared to control concrete is $8.15 \%$.

Mixes with low steel slag and low GGBS gives low strength and the optimum mix with respect to compressive strength is G6S3.

\subsection{Splitting Tensile Strength}

The cylinders were tested in ACTM as shown in fig. 2.

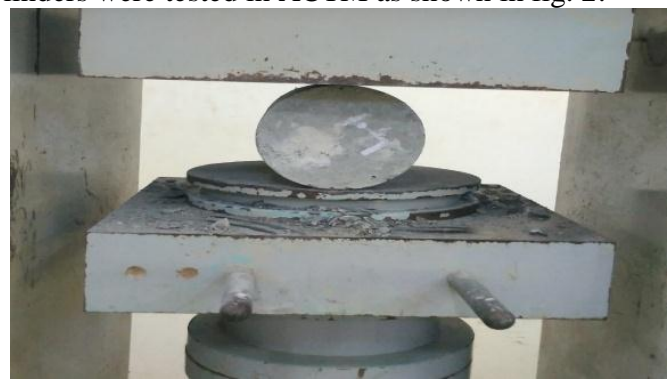

Fig. 2: Splitting tensile strength test setup

Table 3: Splitting Tensile Strength (MPa)

\begin{tabular}{|l|l|l|}
\hline Specimen & 14 days strength & 28 days strength \\
\hline Control & 1.8 & 2.7 \\
\hline G4S1 & 2.63 & 2.69 \\
\hline G5S1 & 2.47 & 2.96 \\
\hline G6S1 & 2.87 & 3.05 \\
\hline G4S2 & 2.70 & 2.85 \\
\hline
\end{tabular}




\begin{tabular}{|l|l|l|}
\hline G5S2 & 2.52 & 2.69 \\
\hline G6S2 & 2.94 & 2.73 \\
\hline G4S3 & 2.76 & 2.84 \\
\hline G5S3 & 2.77 & 2.79 \\
\hline G6S3 & 3.02 & 3.16 \\
\hline
\end{tabular}

The splitting tensile strength of GGBS, steel slag based concrete increased with respect to control concrete. With the increase in the content of steel slag, the splitting tensile strength of specimens increased and this can be seen in the research [8]. The mixes with $50 \%$ GGBS had a reduction in tensile strength but it was more than that of control concrete. The best mix with good tensile strength is G6S3.

\section{Conclusions}

1. Compressive strength decreased for the concrete with composite binder compared to conventional concrete whereas splitting tensile strength increased.

2. As the quantity of GGBS and steel slag increased, compressive strength and splitting tensile strength increased.

3. The percentage increase in strength decrease with further addition of GGBS.

4. The optimum mix is found to be concrete with $60 \%$ GGBS and $30 \%$ steel slag and further increase do not increase the strength further.

5. Addition of steel slag may cause corrosion and the corrosive properties of the mixes can be checked in further studies which would yield better durability of concrete.

\section{References}

[1] Crow, J. M. The concrete conundrum, Chemistry world, 2008, pp. 62-66.

[2] Collins F, Sanjayan JG. The challenge of the cement industry towards the reduction of greenhouse emissions. In: Proceedings of the International Association of Bridge and Structural Engineers (IABSE) conference. September, Melbourne 2002,pp. 1-11.

[3] Global CCS Institute. Introduction: blast furnace slag and steel furnace slag applications. https://hub.globalccsinstitute.com/publications/51-introductionblast-furnace-slag-and-steel-furnace-slag-applications.

[4] Manso JM, Polanco JA, LosanezM,etc. Durability of concrete made with EAF slag as aggregate. Cement Concrete Comp 2006; 28(6), pp. 528-534.

[5] Maslehuddin M, Sharif AM, ShameemM,etc. Comparison of properties of steel slag and crushed limestone aggregate concretes. Constr Build Mater 2003; 17(2), pp. 105-112.

[6] A. Oner, S. Akyuz. An experimental study on optimum usage of GGBS for the compressive strength of concrete. Cement \& Concrete Composites 2007. 29, pp. 505-514.

[7] V. Subathra Devi, B. K. Gnanavel. Properties of concrete manufactured using steel slag. Procedia Engineering 2014, 97, pp. $95-104$

[8] HishamQasrawi, Faisal Shalabi, Ibrahim Asi. Use of low $\mathrm{CaO}$ unprocessed steel slag in concrete as fine aggregate. Construction and building Materials 23 (2009),pp. 1118-1125.

[9] American Society of Testing and Materials (ASTM). "Standard specification for Portland Cement." ASTM C150/C150M-12, ASTM International, West Conshohocken, PA DOI: 10.1520/C0150_C0150M-12.

[10] ACI 211.4R-93 Guide for Selecting Proportions for High-Strength Concrete with Portland Cement and Fly Ash.

[11] American Society for Testing and Materials (ASTM). "Standard specification for concrete aggregate." ASTM C 33, ASTM International, West Conshohocken, PA.

[12] IS 5161959 Methods of Tests for strength of concrete: BIS, New Delhi.

[13] IS 5816:1999 Splitting Tensile Strength of Concrete - Method of Test. 